\title{
Study on Sb-based Alloy and Compound Powder as Lithium Ion Battery Anode Materials
}

\author{
Chengxue Lv, Hangjie Li, Ding Xu and Ruiqin Yang*
}

Zhejiang Provincial Key Lab. for Chem. \& Bio. Processing Technology of Farm Products, School of Biological and Chemical Engineering, Zhejiang University of Science \& Technology, Hangzhou, China

e-mail: yruiqin@163.com

Keywords: $\mathrm{SbFe}$ and $\mathrm{Sb}_{2} \mathrm{Fe}$ alloys; $\mathrm{Sb}-\mathrm{Ge}$ metal composite powder; Lithium ion battery; Anode materials.

Abstract. The $\mathrm{SbFeO}_{3}$ was reduced to obtain the $\mathrm{SbFe}$ and $\mathrm{Sb}_{2} \mathrm{Fe}$ alloys, and the $\mathrm{SbGeO}_{3.5}$ was reduced to obtain the $\mathrm{Sb}-\mathrm{Ge}$ metal composite powder. The simulation lithium ion battery was prepared by using the $\mathrm{SbFe}$ and $\mathrm{Sb}_{2} \mathrm{Fe}$ alloys or the $\mathrm{Sb}-\mathrm{Ge}$ metal composite powder as anode material. The analysis of the XRD and the $\mathrm{SEM}$ for the $\mathrm{SbFe}$ and $\mathrm{Sb}_{2} \mathrm{Fe}$ alloys and the $\mathrm{Sb}-\mathrm{Ge}$ metal composite powder were completed, and the electrochemical properties of the simulation battery were characterized. The results indicate that the first discharge capacity and charge capacity were $510 \mathrm{mAh} / \mathrm{g}$ and $475 \mathrm{mAh} / \mathrm{g}$, and its efficiency was $93.1 \%$ for the $\mathrm{SbFe}$ and $\mathrm{Sb}_{2} \mathrm{Fe}$ alloys. The first discharge capacity and charge capacity were $480 \mathrm{mAh} / \mathrm{g}$ and $425 \mathrm{mAh} / \mathrm{g}$, and its efficiency was $88.5 \%$ for the Sb-Ge metal composite powder. The electric capacity gradually decreased with the charge-discharge cycle number increasing, and the discharge capacity and the charge capacity at 20th week corresponded to $70.6 \%$ and $73.7 \%$ of the initial discharge capacity and the charge capacity for the $\mathrm{SbFe}$ and $\mathrm{Sb}_{2} \mathrm{Fe}$ alloys as anode material, and the discharge capacity and the charge capacity at 20th week corresponded to $78.1 \%$ and $82.4 \%$ of the initial discharge capacity and the charge capacity for the Sb-Ge metal composite powder as anode material. Although the initial electrochemical capacity and the charge/discharge efficiency for the $\mathrm{SbFe}$ and $\mathrm{Sb}_{2} \mathrm{Fe}$ alloys were higher than those for the $\mathrm{Sb}$-Ge metal composite powder, the irreversible capacity loss for the $\mathrm{SbFe}$ and $\mathrm{Sb}_{2} \mathrm{Fe}$ alloys was bigger than that for the $\mathrm{Sb}-\mathrm{Ge}$ metal composite powder as anode material. The reaction mechanism for $\mathrm{SbFe}$ and $\mathrm{Sb}_{2} \mathrm{Fe}$ alloys or Sb-Ge composite powder with the Li was embedding/taking off lithium process. The $\mathrm{SbFe}$ and $\mathrm{Sb}_{2} \mathrm{Fe}$ alloys or the $\mathrm{Sb}-\mathrm{Ge}$ metal composite powder has certain embedded/taking off lithium ability, thus can be used as the candidate material for the lithium ion battery anode active material.

\section{Introduction}

Lithium ion battery has long cycle life, large energy density, high voltage and low self-discharge, good safety performance, no memory effect, pollution-free, etc.[1-3]. It is widely used in many fields. At present, the carbon materials are used commercially as lithium-ion battery anode materials. As anode materials of lithium ion battery, the carbon materials exist poor charge-discharge performance and larger energy loss [4]. The composite oxides and alloy as anode materials have high specific capacity, reversible lithium storage capacity and good conductivity compared with the carbon material. The solvent cannot be inserted and the fast charge-discharge ability is good when these materials are used as lithium ion battery anode materials [5-7].

Although the $\mathrm{Sb}$ single oxide electrochemical capacity is high, its cycle performance is poor. The Sb-based composite oxides were prepared by doping with other elements in single oxide. The cycle performance of the Sb-based composite oxides has been improved, but their irreversible capacity loss is bigger due to the bounded Li into "dead lithium" by the oxygen in active substances reacting with lithium to form $\mathrm{LiO}_{2}$. Therefore, we want to remove oxygen in the composite oxide in order to reduce the irreversible capacity loss.

The Sb-base composite oxide $\mathrm{SbFeO}_{3}$ and $\mathrm{SbGeO}_{3.5}$ were prepared by coprecipitation, and then they were reduced by $\mathrm{H}_{2}$ to obtain the alloys and the metal composite powder. The structure and 
composition of the alloys and the metal composite powder were analyzed by the XRD, and the morphology of the alloys and the metal composite powder was observed by the SEM. The alloys or the metal composite powder was used as the anode material of lithium ion battery to prepare simulation lithium ion battery. The electrochemical performance of the simulation battery was characterized by using the constant current battery automatic tester.

\section{Experimental}

Preperation of alloy and composite powder. The $\mathrm{SbCl}_{3}$ ethanol solution and the $\mathrm{FeCl}_{3} \cdot 6 \mathrm{H}_{2} \mathrm{O}$ ethanol solution were uniformly added to ammonia at stirring and then heating reflux. The obtained products were thermally filtrated, and washed by distilled water to neutral, and then dried at $393 \mathrm{~K}$ for $48 \mathrm{~h}$. The $\mathrm{SbFeO}_{3}$ powder was obtained. The $\mathrm{SbGeO}_{3.5}$ powder was also obtained by the same preparation way.

The $\mathrm{SbFeO}_{3}$ powder was reduced by $\mathrm{H}_{2}$ at $415^{\circ} \mathrm{C}$ for $4 \mathrm{~h}$ to obtain $\mathrm{SbFe}$ and $\mathrm{Sb}_{2} \mathrm{Fe}$ alloys. The $\mathrm{SbGeO}_{3.5}$ powder was reduced by $\mathrm{H}_{2}$ at $580^{\circ} \mathrm{C}$ for $4 \mathrm{~h}$ to obtain $\mathrm{Sb}-\mathrm{Ge}$ composite powder.

The reaction principle is as follows.

$$
\begin{aligned}
& \mathrm{Sb}^{3+}+\mathrm{Fe}^{3+}+6 \mathrm{OH}^{-}=\mathrm{SbFeO}_{3}+3 \mathrm{H}_{2} \mathrm{O} \\
& \mathrm{Sb}^{3+}+\mathrm{Ge}^{4+}+7 \mathrm{OH}^{-}=\mathrm{SbGeO}_{3.5}+7 / 2 \mathrm{H}_{2} \mathrm{O} \\
& \mathrm{SbFeO}_{3(\mathrm{~s})}+3 \mathrm{H}_{2(\mathrm{~g})}=\mathrm{SbFe}_{(\mathrm{s})}+3 \mathrm{H}_{2} \mathrm{O}_{(\mathrm{g})} \\
& 2 \mathrm{SbGeO}_{3.5(\mathrm{~s})}+7 \mathrm{H}_{2(\mathrm{~g})}=2 \mathrm{Sb}_{(\mathrm{s})}+2 \mathrm{Ge}_{(\mathrm{s})}+7 \mathrm{H}_{2} \mathrm{O}_{(\mathrm{g})}
\end{aligned}
$$

Characterization of alloy and composite powder. The product phase was analyzed by using RINT-2200V/PC X-ray diffractometer (CuKa ray $\lambda=1.054056 \AA)$. The voltage was $40 \mathrm{kv}$, and the current was $40 \mathrm{~mA}$, and the scan range 20 800, and the scanning speed 80/min。

The product morphology was analyzed by JSM-6360LV type SEM.

The electrical property of the products was measured by automatic charging and discharging device.

\section{Results and discussion}

XRD analysis. The XRD spectra of samples were indicated in Fig. 1. Fig. 1 a was the $\mathrm{SbFeO}_{3}$ sample no reduced, and b, c, d and e were the sample reduced by $\mathrm{H}_{2}$ at $350^{\circ} \mathrm{C}, 395^{\circ} \mathrm{C}, 405^{\circ} \mathrm{C}, 415^{\circ} \mathrm{C}$, respectively. The results show that the structure of the $\mathrm{SbFeO}_{3}$ was the amorphous due to no observe the obvious diffraction peak in Fig. 1 a. The diffraction peaks of the $\mathrm{Fe}_{2} \mathrm{O}_{3}$ were observed for the reduced sample $\mathrm{SbFeO}_{3}$ at $350^{\circ} \mathrm{C}$ in Fig. 1 b. The diffraction peaks of the $\mathrm{Sb}_{2} \mathrm{O}_{3}, \mathrm{Fe}_{3} \mathrm{O}_{4}, \mathrm{SbFe}$ and $\mathrm{Sb}_{2} \mathrm{Fe}$ were observed for the reduced sample $\mathrm{SbFeO}_{3}$ at $395^{\circ} \mathrm{C}$ and $405^{\circ} \mathrm{C}$ in Fig. $1 \mathrm{c}$ and d. The diffraction peaks of the $\mathrm{SbFe}$ and $\mathrm{Sb}_{2} \mathrm{Fe}$ were observed only for the reduced sample $\mathrm{SbFeO}_{3}$ at $415^{\circ} \mathrm{C}$ in Fig. 1 e. The diffraction peaks of the $\mathrm{Fe}_{2} \mathrm{O}_{3}$ disappeared, while the diffraction peaks of the $\mathrm{Fe}_{3} \mathrm{O}_{4}, \mathrm{Sb}_{2} \mathrm{O}_{3}$, $\mathrm{SbFe}$ and $\mathrm{Sb}_{2} \mathrm{Fe}$ appeared for the reduced sample with reduction temperature rising to $395^{\circ} \mathrm{C}$, and then the peak intensity of the $\mathrm{Fe}_{3} \mathrm{O}_{4}$ receded and the peak intensity of $\mathrm{SbFe}$ and $\mathrm{Sb}_{2} \mathrm{Fe}$ enhanced for the reduced sample with the temperature increasing from $395^{\circ} \mathrm{C}$ to $415^{\circ} \mathrm{C}$. These results indicate that $\mathrm{SbFeO}_{3}$ reduction experienced from $\mathrm{Fe}_{2} \mathrm{O}_{3}$ to $\mathrm{f} \mathrm{Fe}_{3} \mathrm{O}_{4}$ and $\mathrm{Sb}_{2} \mathrm{O}_{3}$, finally to form the $\mathrm{SbFe}$ and $\mathrm{Sb}_{2} \mathrm{Fe}$ alloys.

Fig. 2 a was the $\mathrm{SbGeO}_{3.5}$ sample no reduced, and b, c, d and e were the sample reduced by $\mathrm{H}_{2}$ at $535^{\circ} \mathrm{C}, 550^{\circ} \mathrm{C}, 565^{\circ} \mathrm{C}, 580^{\circ} \mathrm{C}$, respectively. The $\mathrm{SbGeO}_{3.5}$ belonged to the crystal structure due to existing obvious sharp absorption peak in Fig. 2 a. The diffraction peaks of the $\mathrm{GeO}_{2}$ were observed, meanwhile the diffraction peaks of the $\mathrm{Sb}$ and the $\mathrm{Ge}$ were observed also for the reduced sample $\mathrm{SbGeO}_{3.5}$ at temperature reaching to $535^{\circ} \mathrm{C}$, and then the peak intensity of the $\mathrm{GeO}_{2}$ decreased gradually, the peak intensity of the $\mathrm{Sb}$ and the Ge increased gradually with the reduction temperature increasing from $535^{\circ} \mathrm{C}$ to $580^{\circ} \mathrm{C}$. In the end, the peaks of the $\mathrm{SbGeO}_{3.5}$ and $\mathrm{GeO}_{2}$ disappeared thoroughly, the pears of the $\mathrm{Sb}$ and the Ge were observed only for the reduced sample at temperature $580^{\circ} \mathrm{C}$. This shows that all $\mathrm{SbGeO}_{3.5}$ was reduced completely to form metal $\mathrm{Sb}$ and $\mathrm{Ge}$ at reduction temperature $580^{\circ} \mathrm{C}$. The separate diffraction peak of the $\mathrm{Sb}$ or Ge was observed, and the diffraction peak of the alloy was not observed. Therefore, the $\mathrm{SbGeO}_{3.5}$ was reduced to obtain the $\mathrm{Sb}-\mathrm{Ge}$ 
composite powder instead of the alloy. It implies that the alloy could not be formed by the reducing the $\mathrm{SbGeO}_{3.5}$ at $580^{\circ} \mathrm{C}$.

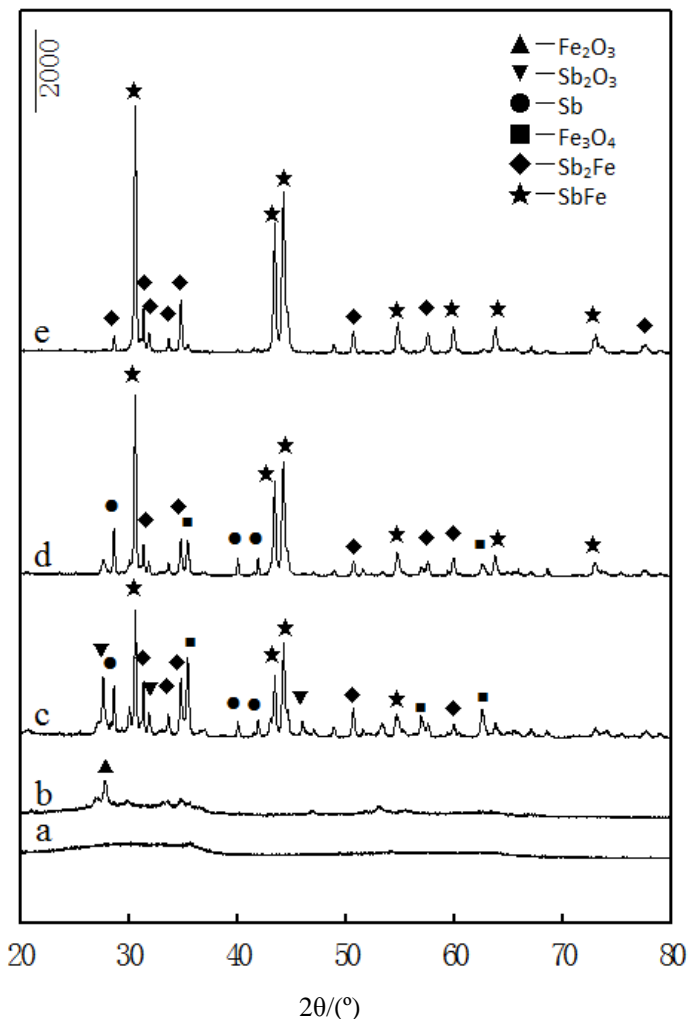

Fig. 1. XRD patterns of samples reduced by $\mathrm{H}_{2}$ (a. $\mathrm{SbFeO}_{3}$, b. c. d. and e. reduced at $350^{\circ} \mathrm{C}, 395^{\circ} \mathrm{C}, 405^{\circ} \mathrm{C}, 415^{\circ} \mathrm{C}$ )

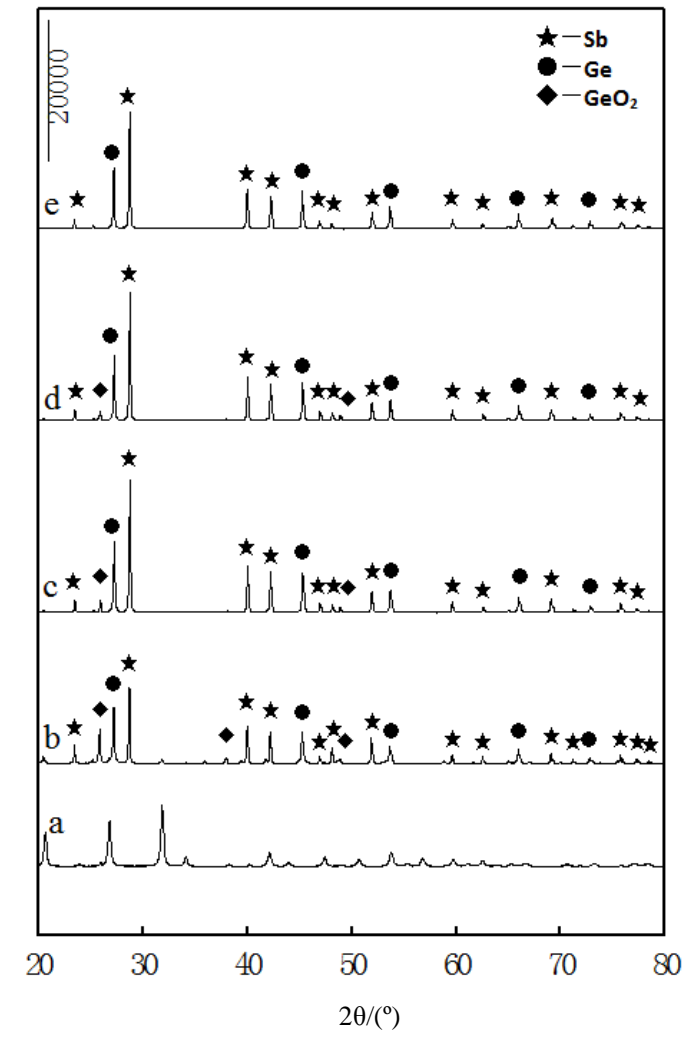

Fig. 2. XRD patterns of samples reduced by $\mathrm{H}_{2}$ (a. $\mathrm{SbGeO}_{3.5}$, b. c. d. and e. reduced at $535^{\circ} \mathrm{C}, 550^{\circ} \mathrm{C}, 565^{\circ} \mathrm{C}, 580^{\circ} \mathrm{C}$ )

SEM analysis. The morphology of the $\mathrm{SbFe}$ and $\mathrm{Sb}_{2} \mathrm{Fe}$ alloys was characterized by the SEM. Fig. 3 is the SEM image of the the $\mathrm{SbFe}$ and $\mathrm{Sb}_{2} \mathrm{Fe}$ alloys. The results indicate that alloy particles were uniform, and multiple particles formed a typical honeycomb mass of particles with obvious network structure. The average particle size of particles is about $100 \mathrm{~nm}$.

Fig. 4 is morphology of the Sb-Ge composite powder characterized by the SEM. The results show that the particle distribution of the Sb-Ge metal composite powder were uniform, and presenting small ball shape, and gathered together to bigger ball shape. The average particle size of particles is about $100 \mathrm{~nm}$.

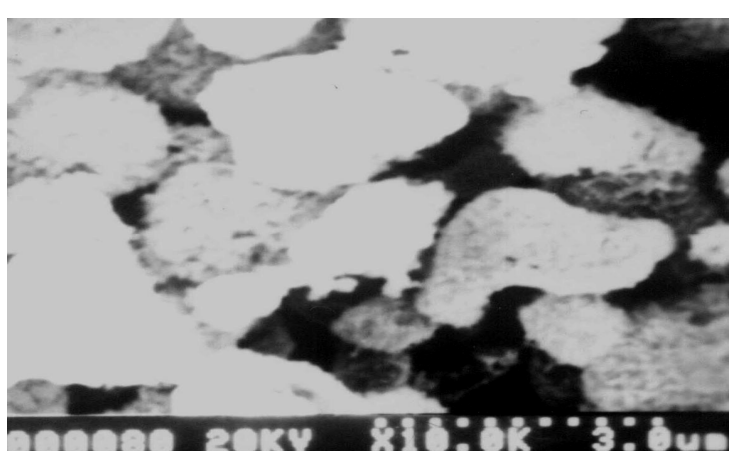

Fig. 3. SEM image of $\mathrm{SbFe}$ and $\mathrm{Sb}_{2} \mathrm{Fe}$ alloy

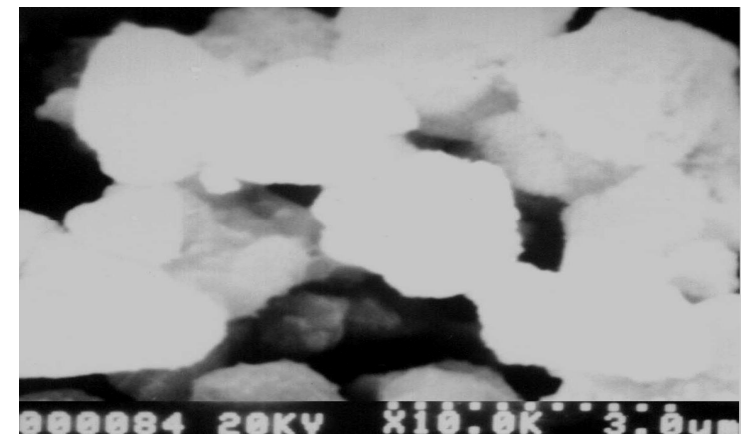

Fig. 4. SEM image of Sb-Ge metal compound powde

Electrochemical properties. The charge and discharge curves of the simulation battery using the $\mathrm{SbFe}$ and $\mathrm{Sb}_{2} \mathrm{Fe}$ alloys as lithium ion battery anode material were observed in Fig. 5. Table I was electrochemical properties of $\mathrm{SbFe}$ and $\mathrm{Sb}_{2} \mathrm{Fe}$ alloys and $\mathrm{Sb}-\mathrm{Ge}$ metal composite powder. The results indicate that the first discharge capacity (embedding lithium capacity) was $510 \mathrm{mAh} / \mathrm{g}$, the first charge capacity (taking off lithium capacity) was $475 \mathrm{mAh} / \mathrm{g}$, and its efficiency was $93.1 \%$. In the first week of the discharge curve, there was the slope at higher voltage than $0.8 \mathrm{~V}$, and no longer present at 
following cycle. This was the decomposition reactions of SbFe surface oxide. Relative to the discharge platform at discharging curves $0.8 \mathrm{~V}$, the corresponding charge platform could be seen at charging curve $1.1 \mathrm{~V}$. This was typical of Li-Sb alloy reaction. The electric potential of reversible embedding lithium platform was $0.8 \mathrm{~V}$ and $0.25 \mathrm{~V}$, and the corresponding electric potential of reversible taking off lithium platform was about $1.1 \mathrm{~V}$ and $0.5 \mathrm{~V}$. After 20 cycles, its discharge capacity was $360 \mathrm{mAh} / \mathrm{g}$, accounting for $70.6 \%$ of the initial discharge capacity, and charging capacity was $350 \mathrm{mAh} / \mathrm{g}$, accounting for $73.7 \%$ of the initial charge capacity, and the efficiency was $97.2 \%$. In $\mathrm{SbFe}$ and $\mathrm{Sb}_{2} \mathrm{Fe}$ alloys, the $\mathrm{Sb}$ as active group (single active group) reacted with $\mathrm{Li}^{+}$to generate $\mathrm{Li}_{\mathrm{y}} \mathrm{Sb}(\mathrm{y} \leq 3)$.

Fig. 6 is charge and discharge curves of the simulation battery by the Sb-Ge metal composite powder as lithium ion battery anode material. Table I was electrochemical properties of $\mathrm{SbFe}$ and $\mathrm{Sb}_{2} \mathrm{Fe}$ alloys and $\mathrm{Sb}-\mathrm{Ge}$ metal composite powder. The results indicate that the first discharge capacity was $480 \mathrm{mAh} / \mathrm{g}$, the first charge capacity was $425 \mathrm{mAh} / \mathrm{g}$, and its efficiency was $88.5 \%$. There were 2 obvious embedding lithium platform electric potential in the first week of discharge process at $0.75 \mathrm{~V}$ and $0.2 \mathrm{~V}$, and its reversible taking off lithium platform electric potential was about $0.5 \mathrm{~V} \sim 1.1 \mathrm{~V}$. After 20 cycles, its discharge capacity was $375 \mathrm{mAh} / \mathrm{g}$, accounting for $78.1 \%$ of the initial discharge capacity, and charging capacity was $350 \mathrm{mAh} / \mathrm{g}$, accounting for $82.4 \%$ of the initial charge capacity, and the efficiency was 93.3\%. In Sb-Ge metal composite powder, both $\mathrm{Sb}$ and $\mathrm{Ge}$ as active group (double active group) reacted with $\mathrm{Li}^{+}$to generate $\mathrm{Li}_{y} \mathrm{Sb}(\mathrm{y} \leq 3)$ and $\mathrm{Li}_{x} \mathrm{Ge}(\mathrm{x} \leq 4.4)$.

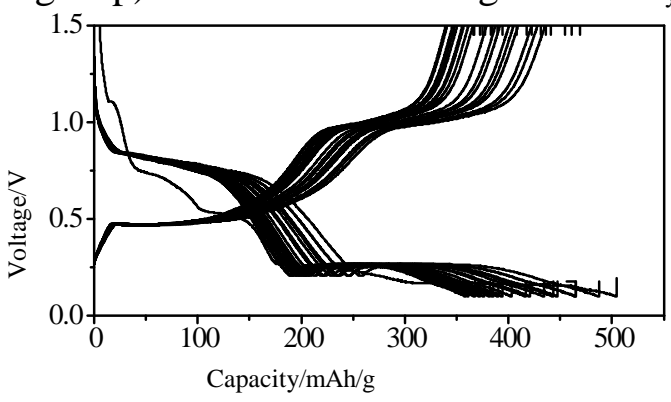

Fig. 5. Charge and discharge curves of the simulation battery for $\mathrm{SbFe}$ and $\mathrm{Sb}_{2} \mathrm{Fe}$ alloy as lithium ion battery anode materials

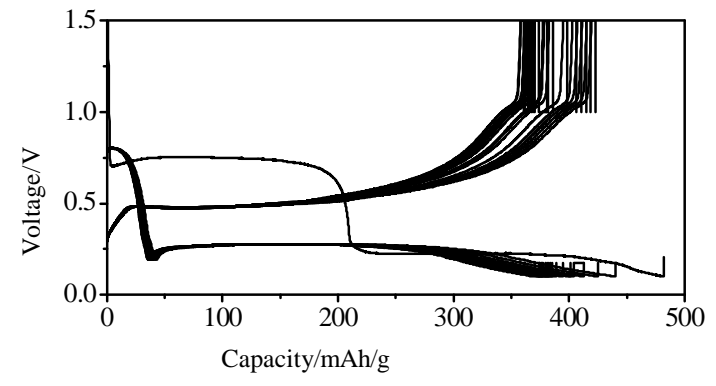

Fig. 6. Charge and discharge curves of the simulation battery for Sb-Ge composite powder as lithium ion battery anode materials

Table 1 Electrochemical properties of Sb-based Alloy and metal composite powder

\begin{tabular}{|c|c|c|c|}
\hline \multirow{2}{*}{ Samples } & \multicolumn{2}{|c|}{ First charge and discharge capacity $(\mathrm{mAh} / \mathrm{g})$} & \multirow{2}{*}{ Efficiency $(\%)$} \\
\hline & Discharge & Charge & \\
\hline $\mathrm{Sb}-\mathrm{Ge}$ & 480 & 425 & 88.5 \\
\hline $\mathrm{SbFe} \mathrm{Sb}_{2} \mathrm{Fe}$ & 510 & 475 & 93.1 \\
\hline \multirow{2}{*}{ Samples } & \multicolumn{2}{|c|}{ Charge and discharge capacity at 20th weeks $(\mathrm{mAh} / \mathrm{g})$} & Efficiency $(\%)$ \\
\hline & Discharge & Charge & \\
\hline $\mathrm{Sb}-\mathrm{Ge}$ & 375 & 350 & 93.3 \\
\hline $\mathrm{SbFe} \mathrm{Sb}_{2} \mathrm{Fe}$ & 360 & 350 & 97.2 \\
\hline
\end{tabular}

\section{Conclusions}

The Sb-based composite oxide $\left(\mathrm{SbFeO}_{3}, \mathrm{SbGeO}_{3.5}\right)$ was prepared by coprecipitation method. The Sb-based composite oxide could be reduced smoothly by $\mathrm{H}_{2}$ using self-designed closed loop system under low temperature. The reduction product of the $\mathrm{SbFeO}_{3}$ was alloys $\left(\mathrm{SbFe}\right.$ and $\left.\mathrm{Sb}_{2} \mathrm{Fe}\right)$, and the reduction product of the $\mathrm{SbGeO}_{3.5}$ was the metal composite powder ( $\mathrm{Sb}-\mathrm{Ge}$ ). The reduction reaction of the $\mathrm{Sb}$-based composite oxide by $\mathrm{H}_{2}$ in closed loop system generated easily, and the product particle size was smaller than $200 \mathrm{~nm}$.

The capacity gradually decreased with the charge-discharge cycle number increasing, and the discharge capacity at 20th week corresponded to $70.6 \%$ of the initial discharge capacity, and the charge capacity at 20th week corresponded to $73.7 \%$ of the initial charge capacity, and the charge/discharge efficiency was $97.2 \%$ after 20 cycles for the $\mathrm{SbFe}$ and $\mathrm{Sb}_{2} \mathrm{Fe}$ alloys as lithium ion battery anode material. The capacity gradually decreased with the charge-discharge cycle number 
increasing, and the discharge capacity at 20th week corresponded to $78.1 \%$ of the initial discharge capacity, and the charge capacity at 20th week corresponded to $82.4 \%$ of the initial charge capacity, and the charge/discharge efficiency was $93.3 \%$ after 20 cycles for the Sb-Ge metal composite powder as lithium ion battery anode material.

As lithium ion battery anode material, although the initial electrochemical capacity and the charge/discharge efficiency for the $\mathrm{SbFe}$ and $\mathrm{Sb}_{2} \mathrm{Fe}$ alloys was higher than those for the Sb-Ge metal composite powder, the irreversible capacity loss for the $\mathrm{SbFe}$ and $\mathrm{Sb}_{2} \mathrm{Fe}$ alloys was bigger than that for the $\mathrm{Sb}-\mathrm{Ge}$ metal composite powder as lithium ion battery anode material.

The $\mathrm{SbFe}$ and $\mathrm{Sb}_{2} \mathrm{Fe}$ alloys and $\mathrm{Sb}-\mathrm{Ge}$ composite powder as active material of a lithium ion battery anode materials reacted with the lithium in the process of charging and discharging, and its reaction mechanism was embedding/taking off lithium reactions of the lithium with the metal by alloying/dealloying. The $\mathrm{SbFe}$ and $\mathrm{Sb}_{2} \mathrm{Fe}$ alloys or the $\mathrm{Sb}-\mathrm{Ge}$ metal composite powder has certain embedded/taking off lithium ability, thus can be used as the candidate material for the lithium ion battery anode active material.

\section{Acknowledgment}

This work was financially supported by the Interdisciplinary Research Fund of Zhejiang University of Science \& Technology (2013JC09Y) and Zhejiang Province Research project of public welfare Technology Application (2015C33006, 2015C32019).

\section{References}

[1] Y. Kubota, M. C. S. Escano, H.Nakanishi, et al. Journal of Alloys and Compounds 458 ( 2008) 151-157.

[2] J. Li, J. R. Dahn, J Electrochem Soc. 154 (2007) A156-A161.

[3] N. H.Zhao, L. C. Yang, P. Zhang, et al. Materials Letters 64 (2010) 972- 975.

[4] W. Qiu, G. Zhang, S. Lu, Q. Liu, Solid State Ionics 73 (1999) 121-125.

[5] X. Lou, C. Li, L. Archer, Advanced Materials 21 (2009) 2536-2539.

[6] J. T. Vaughey, L. Fransson, H. A. Swinger, et al. J. Power Sources 119-121 (2003) 64-68.

[7] Y. Hu, H. Zhang, H. Yang, J. Alloys Compd. 428 (2007) 327- 331. 